\title{
Winter cover crops influence weed establishment and nitrogen supply to maize
}

\section{Plantas de cobertura de invierno suprimen malezas y proveen $\mathrm{N}$ al maíz cultivado en sucesión}

\author{
Hugo Abelardo González Villalba1,2*, Dorivar Ruiz Diaz², Evandro Luiz Schoninger ${ }^{3}$ \\ y Carlos Andrés Leguizamón Rojas ${ }^{4}$
}

\footnotetext{
${ }^{1}$ Escola Superior de Agricultura Luiz de Queiroz, Departamento de Ciência do Solo. Piracicaba, SP, Brazil.

${ }^{2}$ Kansas State University, Department of Agronomy. Manhattan, KS 66506, United State.

${ }^{3}$ Universidade Estadual de Mato Grosso, Departamento de Agronomia. Alta Floresta, MT, Brazil.

${ }^{4}$ Universidad Nacional de Asunción, Departamento de Suelos y Ordenamiento Territorial. San Lorenzo, Paraguay.
}

*Correspondence author: hugoabelardo1988@usp.br

Conflict of interest: The authors declare no conflict of interest.

\section{License:}

Creative Commons CC-BY

History:

Received: $25 / 04 / 17$

Accepted: $08 / 11 / 18$

\begin{abstract}
Cover crops (CC) and crop rotation are key components of a sustainable crop production system. The objectives of this study were to (i) evaluate the effect of winter CC on nitrogen $(\mathrm{N})$ supply to the subsequent maize crop, and to (ii) evaluate the effect of $\mathrm{CC}$ on soil cover and weed population. Three winter CC were evaluated: black oat (BO) (Avena strigosa Schieb), white lupin (WL) (Lupinus albus), and oilseed radish (OR) (Raphanus sativus L.), as single species and in a mix. The three CC mixes included: $\mathrm{BO}+\mathrm{WL} ; \mathrm{BO}+\mathrm{OR}$; and $\mathrm{OR}+\mathrm{WL}$. In addition to $\mathrm{CC}$ treatments a set of five $\mathrm{N}$ application rates $\left(0,60,120,180\right.$, and $\left.240 \mathrm{~kg} \mathrm{~N} \mathrm{ha}^{-1}\right)$ were included on plots under winter fallow (WF). The winter CC supplied plant-available $\mathrm{N}$ to the subsequent maize crop varying from 25 to $53 \mathrm{~kg} \mathrm{~N}^{-1}$ with $\mathrm{BO}$ and $\mathrm{WL}$, respectively. The mix of CC varied less in $\mathrm{N}$ supply (38-42 $\mathrm{kg} \mathrm{N} \mathrm{ha}^{-1}$ ). Soil cover and weed suppression varied between CC. The results suggest that $\mathrm{BO}$ can be used to attain rapid soil cover. Black oats also provided better soil cover after $\mathrm{CC}$ flattening, likely due to the higher $\mathrm{C}: \mathrm{N}$ ratio and slower residue decomposition. The higher $\mathrm{C}: \mathrm{N}$ ratio may result in some $\mathrm{N}$ immobilization and reduced plant available $\mathrm{N}$ to the maize crop. However, $\mathrm{BO}$ also showed great weed suppression. Mixing CC is an alternative to merge the benefits of the individual species, enhancing the overall ecosystem services provided by them.
\end{abstract}

Key words: crop rotation, fertilizer nitrogen, green manure, soil cover, weeds.

\section{RESUMEN}

Plantas de cobertura (PC) y rotación de cultivos son componentes esenciales de un sistema de producción agrícola sostenible. Los objetivos de este estudio fueron (i) evaluar el efecto de PC en la provisión de nitrógeno $(\mathrm{N})$ al maíz cultivado en sucesión, y (ii) evaluar el efecto de PC en la cobertura de suelo (CS) y supresión de malezas (SM). Tres PC de invierno fueron evaluadas: avena negra (AN) (Avena strigosa Schieb), lupino blanco (LB) (Lupinus albus), y nabo forrajero (NF) (Raphanus sativus L.), en forma asociada y no asociada. Las asociaciones fueron: AN+LB, AN+NF, y NF+LB. Además, fueron incluidas cinco dosis de $N\left(0,60,120,180\right.$, y $\left.240 \mathrm{~kg} \mathrm{ha}^{-1} \mathrm{~N}\right)$ en parcelas en situación de barbecho. Las PC proporcionaron $\mathrm{N}$ mineral al maíz en sucesión, variando de 25 a $53 \mathrm{~kg} \mathrm{ha}^{-1} \mathrm{~N}$ en el caso de $A N$ y LB, respectivamente. Las asociaciones de PC proporcionaron el equivalente a $38-42 \mathrm{~kg} \mathrm{ha}^{-1} \mathrm{~N}$ fertilizante. La CS y la SM variaron con cada PC. Los resultados sugieren que AN puede proporcionar rápida CS, y una CS más prolongada después del acamado, probablemente debido a la alta relación $\mathrm{C}: \mathrm{N}$ y lenta descomposición de sus residuos, lo que podría resultar en inmovilización de $\mathrm{N}$ y disminución de su disponibilidad para el maíz. La AN también demostró buena capacidad de supresión de malezas. La asociación de PC es una alternativa que permite combinar los beneficios de cada especie de PC, mejorando los servicios al ecosistema promovidos por las mismas.

Palabras clave: abonos verdes, cobertura de suelo, fertilizante nitrogenado, malezas, rotación de cultivos. 


\section{INTRODUCTION}

The use of cover crops (CC) is essential to improve overall soil health, providing key ecosystem services through increased plant diversity (Finney et al. 2016). The benefits of CC in combination with notill system (NT) on the succeeding crops is well documented worldwide (Albuquerque et al. 2015, Fontoura and Bayer 2009, Giacomini et al. 2004, Varela et al. 2014). However, there is a lack of information in the scientific literature for some regions of South America such as Paraguay, where NT is adopted today in more than $90 \%$ of the agricultural land (Derpsch et al. 2016). The use of winter CC in crop rotations is considered more suitable than summer $\mathrm{CC}$ due to the same spacetime occupation with summer cash crops (Florentin et al. 2011).

Optimum nitrogen ( $\mathrm{N}$ ) supply and proper weed control is often considered the main challenges for maize production, especially under NT system (Bender et al. 2013, Lundy et al. 2015). Nitrogen immobilization can be higher under NT system due to the presence of high amounts of plant residues on the soil surface (Frasier et al. 2016), and weed control typically relies on chemical control (Hodgdon et al. 2016, Kaundun et al. 2014). Legume CC can provide $\mathrm{N}$ for the succeeding crop (Florentin et al. 2011, Mahama et al. 2016), with the potential of replacing part of the fertilizer $\mathrm{N}$ application (Fontoura and Bayer 2009, Mahama et al. 2016, Tully et al. 2015). The amount of available $\mathrm{N}$ supply from CC depends on several factors: total $N$ uptake by the plants, timely $\mathrm{N}$ mineralization from the residue, $\mathrm{N}$ availability for the next crop, rainfall during the cropping season, and the technology level adopted in the farming systems (BlancoCanqui et al. 2015, Giacomini et al. 2004).

Three common winter CC species in South America are black oat (BO), white lupin (WL) and oilseed radish (OR). As stated by Tosti et al. (2014), mixtures of CC may be an efficient alternative to merge benefits of the individual species, improving the overall ecosystem services provided by their inclusion in the crop rotation system (Blanco-Canqui et al. 2015, Ramirez-Garcia et al. 2015). Research studying winter CC (as single specie or mix) on $\mathrm{N}$ supply and weed control for maize production has yet to be conducted on typical Ultisol soils in South America. The objectives of this study were to (i) evaluate the $\mathrm{N}$ supply from winter $\mathrm{CC}$ to the subsequent maize crop, and to (ii) evaluate the effect of CC on weed population, soil cover, biomass production, and $\mathrm{N}$ uptake of the cover crops and the subsequent maize crop.

\section{MATERIAL AND METHODS}

A field experiment was conducted in Caaguazú, Eastern Region of Paraguay ( $25^{\circ} 27^{\prime} 04^{\prime \prime}$ South and $55^{\circ} 54^{\prime} 10^{\prime \prime}$ West) during the 2010/2011 growing season. The annual mean rainfall of this area fluctuates between $1700-2000 \mathrm{~mm}$, with a mean temperature of $21^{\circ} \mathrm{C}$ (DMH 2015).

The experiment was carried out on a sandy loam Rhodic Paleudult, with $0-3 \%$ slope and good drainage, (Lopez et al. 1995). Soil samples were taken from the $0-$ to $10-$ and $10-$ to $20-\mathrm{cm}$ depth across the experimental site before the establishment of the study (Table 1 ).

Soil samples were air-dried, ground to pass a $2 \mathrm{~mm}$ sieve and analyzed for soil $\mathrm{pH}$ in a 1:1 water suspension (Tedesco et al. 1995). Soil texture was determined by the hydrometer method (Bouyoucos 1962). Soil organic carbon (SOC) was determined by the Walkley-Black method (Tedesco et al. 1995) and soil total nitrogen (STN) by the Kjeldahl digestion method. Soil $\mathrm{P}, \mathrm{K}, \mathrm{Ca}$ and $\mathrm{Mg}$ were analyzed using the Mehlich-1 extraction (Tedesco et al. 1995). Soil potential acidity $(\mathrm{H}+\mathrm{Al})$ was measured with the SMP buffer method (Shoemaker et al. 1961). Cation exchange capacity (CEC) at pH 7.0 was calculated by adding the exchangeable basic cations $\mathrm{Ca}^{+2}, \mathrm{Mg}^{+2}$ and $\mathrm{K}^{+}$and the potential acidity (H+Al) (Raij 2011). Base saturation was calculated dividing the values of the basic cations by CEC and then multiplied by 100 (Raij 2011). Soil nitrate $\left(\mathrm{NO}_{3}{ }^{-}-\mathrm{N}\right)$ was extracted with $\mathrm{KCl} 1 \mathrm{M}$ and then analyzed with the Kjeldahl distillation (Tedesco et al 1995). The results of the analysis are presented in Table 1. The experimental site has a history of approximately 35 years under crop production using low input (fertilizer or pesticides) and under conventional-tillage. Crops included in the rotation for this region include sugarcane (Saccharum spp.) with maize and pasture cultivated every three years, and the study area had no recent history of fertilizer application. Lime was surface-applied two months before the establishment of the study based on soil test results.

The experimental design was randomized complete block with three replications. Three winter CC were adopted: black oat (BO), white lupin (WL), and 
oilseed radish (OR), as single species and in a mix. The three $\mathrm{CC}$ mixes included: black oat and white lupin $(B O+W L)$; black oat and oilseed radish (BO + OR); and oilseed radish and white lupin (OR +
$\mathrm{WL}$ ). In addition to CC treatments, a set of five $\mathrm{N}$ application rates were included on plots under winter fallow (WF). Nitrogen rates were 0, 60, 120, 180 and $240 \mathrm{~kg} \mathrm{~N} \mathrm{ha}^{-1}$.

Table 1. Selected physicochemical soil properties of a subtropical Ultisol under transition from conventional tillage to no-till system, sampled at 0 - to $10-$ and at $10-$ to $20-\mathrm{cm}$ depth.

\begin{tabular}{|c|c|c|c|c|c|c|c|c|c|c|c|c|}
\hline Depth & $\mathrm{pH}$ & Clay & soct & STN $\neq$ & $P$ & $\mathrm{~S}$ & $\mathrm{~K}$ & $\mathrm{Ca}$ & $\mathrm{Mg}$ & $\mathrm{H}+\mathrm{Al}$ & CECף & $\begin{array}{c}\text { BS } \\
\#\end{array}$ \\
\hline $\mathrm{m}$ & & --- & $-\mathrm{g} \mathrm{kg}^{-}$ & $-\cdots$ & $-m g$ & $m^{-3}-$ & - & --- & $\mathrm{mm}$ & lc $\mathrm{dm}^{-3}$ & $-\cdots$ & $\%$ \\
\hline $0.0-0.1$ & 6.5 & 100 & 5.1 & 0.6 & 5.2 & 4.6 & 3 & 30 & 7 & 49 & 89 & 45 \\
\hline $0.1-0.2$ & 6.3 & 93 & 4.4 & 0.6 & 3.9 & 4.5 & 2 & 24 & 6 & 49 & 82 & 40 \\
\hline
\end{tabular}

Cover crops were planted on June 2010 with the following seeding rates: $60 \mathrm{~kg} \mathrm{ha}{ }^{-1}$ of $\mathrm{BO} ; 140 \mathrm{~kg}$ $\mathrm{ha}^{-1}$ of $\mathrm{WL} ; 20 \mathrm{~kg} \mathrm{ha}^{-1}$ of $\mathrm{OR} ; 30 \mathrm{~kg} \mathrm{ha}^{-1}$ of $\mathrm{BO}+80$ $\mathrm{kg} \mathrm{ha}^{-1}$ of WL; $35 \mathrm{~kg} \mathrm{ha}^{-1}$ of $\mathrm{BO}+8 \mathrm{~kg} \mathrm{ha}^{-1}$ of OR; and $10 \mathrm{~kg} \mathrm{ha}^{-1}$ of OR $+80 \mathrm{~kg} \mathrm{ha}^{-1}$ of WL. No fertilizer was applied to the CC. The cover crops were killed by hand at flowering (approximately 120 days after planting), using a machete in order to imitate the passing of a knife-roller. Maize (hybrid DEKALB 390) was planted with a hand-held planter into the CC stubble immediately after CC flattening. Rowspacing was $80 \mathrm{~cm}$ and seeding rate 55,000 seeds $\mathrm{ha}^{-1}$. Plot sizes were $5 \mathrm{~m}$ long and 6 rows wide. Phosphorus and $\mathrm{K}$ fertilizer were band applied at maize planting ( $5 \mathrm{~cm}$ from the row) at a rate of 60 $\mathrm{kg} \mathrm{P}_{2} \mathrm{O}_{5}$ and $\mathrm{K}_{2} \mathrm{O} \mathrm{ha}^{-1}$ based on fertilizer recommendation by Fatecha (1999). Urea fertilizer was band applied at $30 \mathrm{~kg} \mathrm{~N} \mathrm{ha}^{-1}$ at planting. The remaining of the $\mathrm{N}$ rate for each treatment was broadcasted by hand at the V6 growth stage (Abendroth et al. 2011), ensuring an even distribution of the fertilizer.

Cover crops were evaluated for: soil cover (SC), number of weeds (NW), CC biomass production (BP), CC nitrogen uptake (NU), and soil mineral nitrogen (SMN). Maize biomass (MB), maize grain nitrogen uptake (GNU), and maize grain yield (GY) were measured. For SC assessment a $1 \mathrm{~m}^{2}$ frame divided into 400 equal squares of $25 \mathrm{~cm}^{2}$ each was used. Every square was considered covered if at least $50 \%$ was covered by the plants or plant residues. Measurements were completed at 30, 60, $90,120,150$, and 180 days after CC planting (DAP). Weed plants were counted in a $1 \mathrm{~m}^{2}$ area marked with a wood frame whereas weeds were counted on the inside at 60, 120, and 180 DAP. For SMN extraction at the field, $20 \mathrm{~g}$ of composite samples were weighed and transferred to snap-cap bottles containing $100 \mathrm{ml} \mathrm{KCl} 1 \mathrm{~mol} \mathrm{~L}^{-1}$ as recommended by
Tedesco et al. (1995). Approximately $100 \mathrm{~g}$ of soil samples were also taken in hermetically closed plastic bags for soil humidity determination and transported in ice containing cooler. Ammonium $\left(\mathrm{NH}_{4}{ }^{+}\right)$and nitrate $\left(\mathrm{NO}_{3}{ }^{-}\right)$content were determined together by the micro-Kjeldhal method (Tedesco et al. 1995). Nitrite $\left(\mathrm{NO}_{2}{ }^{-}\right)$concentrations were considered minimal and results expressed as $\mathrm{NH}_{4}{ }^{+}$ $+\mathrm{NO}_{3}{ }^{-}$.

Cover crop biomass production (BP) was measured collecting samples on a $0.5 \mathrm{~m}^{2}$ area in random points within the plots. Sub-samples were oven dried at $65^{\circ} \mathrm{C}$ for 72 hours and weighed, ground on a Wiley mill and analyzed for $\mathrm{N}$ by the microKjeldhal method (Tedesco et al. 1995). Maize biomass (MB) was measured collecting six plants per plot before harvest. Ears were separated from the plants and ears and plants oven-dried at $65^{\circ} \mathrm{C}$ for 96 hours and then weighed. For GNU determination, the grains were ground in Wiley mill and analyzed for $\mathrm{N}$ content by the micro-Kjeldhal method. Grain yield was measured by hand harvesting the two center rows of each plot. Grain yield is expressed on a $150 \mathrm{~g} \mathrm{~kg}^{-1}$ moisture basis.

Data was analyzed using block as a random effect in the model. Cover crops, maize and soil parameters were analyzed using the PROC GLIMMIX and PROC REG in SAS 9.4 software (SAS Institute 2014). To assess the significance of differences between means we used the LSMEANS and slice option in PROC GLIMMIX, which provides a general mechanism for performing a partitioned analysis of the LSMEANS for a specific interaction (i.e. analysis of simple effects). Treatments effects were considered statistically significant at the $P \leq 0.10$ probability level. 


\section{RESULTS Y DISCUSSION}

During the growing season a total rainfall of $260 \mathrm{~mm}$ accumulated during the CC phase (from June to October 2010), and $786 \mathrm{~mm}$ during the maize phase (from October 2010 to February 2011) (Figure 1). The CC received less total rain than the 30 years average for this region, while the maize crop received similar amount of water. The total observed rainfall was $1046 \mathrm{~mm}$ (CC + maize phase), and together with the mean temperature observed during the study was generally in line with the long-term average (30 years) for this region (Figure 1).

The measurements during the $\mathrm{CC}$ phase showed that SC and NW were affected significantly by the interaction of CC by sampling date (Table 2). Soil cover was consistently lower for winter fallow in comparison to CC treatments, except at the last sampling date when it was similar to $\mathrm{OR}+\mathrm{WL}$ and single WL (Figure 2). This demonstrates why the adoption of no-till and the use of cover crops in the rotation are necessary to build up a stronger and sustainable cropping system (Albuquerque et al. 2015, Blanco-Canqui et al. 2015). On the other hand, BO showed significantly higher SC early after CC planting, as well as higher SC after flattening and the immediate maize planting. These results suggest that $\mathrm{BO}$ can potentially provide improved soil protection during the winter months before maize planting, but also provide cover during the early growth stages for maize. Soil cover for mix CC species was generally improved when $\mathrm{BO}$ was present in the mix (Figure 2). Soil protection is particularly important for soil conservation and sustainable crop production under subtropical conditions in South America, where the climate is predominantly warm and humid (Derpsch et al. 2014). Live or dead SC provides protection from soil erosion, helps to maintain surface soil moisture and control the thermal regime (Blanco-Canqui et al. 2015). Effective soil cover is one of the greatest advantages when using $\mathrm{CC}$ in a no-till system.

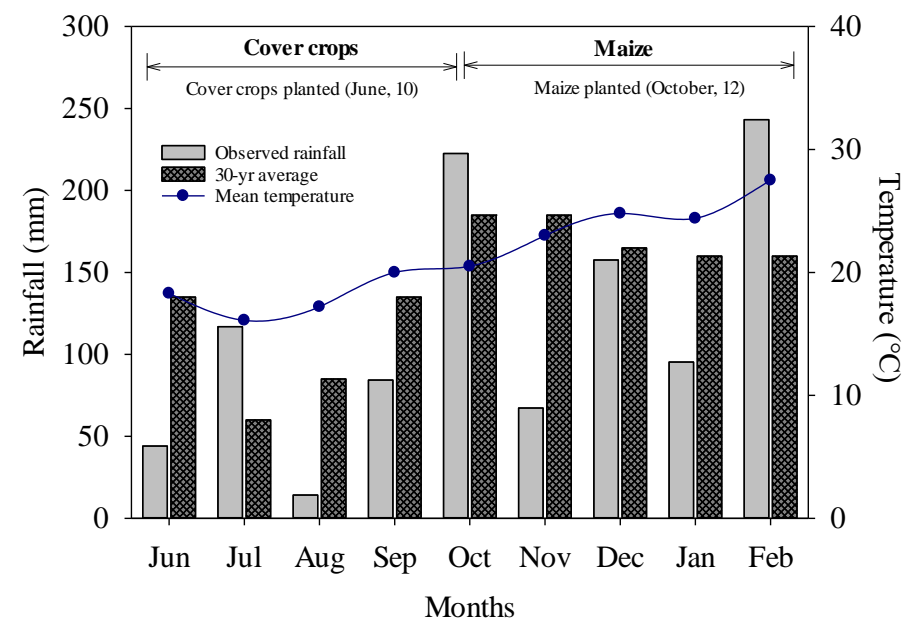

Figure 1. Total rainfall observed monthly, 30 years rainfall average, and mean temperature during the experiment (DMH 2015).

Table 2. Significance of probability values from the analysis of variance for soil cover (SC), number of weeds (NW), and soil mineral nitrogen (SMN) as affected by single species cover crops, combinations and winter fallow, during the 2009-2010 cropping season.

\begin{tabular}{|c|c|c|c|}
\hline \multirow{2}{*}{ Main effect } & Soil cover & Number of weeds & Soil mineral $\mathrm{N}$ \\
\hline & \multicolumn{3}{|c|}{ 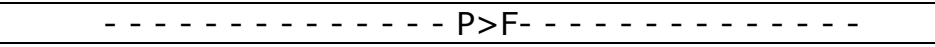 } \\
\hline Cover crop (CC) & $<0.001$ & $<0.001$ & $<0.001$ \\
\hline Sampling date (SD) † & $<0.001$ & $<0.001$ & $<0.001$ \\
\hline $\mathrm{CC} \times \mathrm{SD}$ & 0.001 & $<0.001$ & 0.349 \\
\hline
\end{tabular}

+ Sampling date, days after cover crops planting for SC and NW; and days after maize planting for SMN. 
The number of weeds was significantly reduced using CC when compared to winter fallow (Figure 3 ). The suppression of weed population followed similar trends as the SC provided by the different $\mathrm{CC}$ treatments, and the lowest weed population was attained with the use of $\mathrm{BO}$ (Figure 2 and 3). The low weed population with $\mathrm{BO}$ can be due in part to the quick and lasting $\mathrm{SC}$ in addition to hindering weed growth from the $\mathrm{BO}$ on some weed species (Flower et al. 2012, Price et al. 2006). Previous studies found similar results with the use of CC preventing or reducing weed infestation (Florentin et al. 2011, Hodgdon et al. 2016). This becomes particularly important in modern agricultural systems worldwide given the current herbicideresistance problems worldwide (Kaundun et al.
Lower soil cover and higher NW were found for the legume CC (WL). However, the use of mixture of cover crops was a useful strategy to improve these parameters and as reported in previous studies (Finney et al. 2016), all the CC treatments provided some improvement for SC and suppression of weeds while bare soil during the winter provided an open window for weed infestation. Eradication of these weeds can be costly and is becoming increasingly difficult (Hodgdon et al. 2016, Kaudun et al. 2014), thus, it is important to highlight the great ecosystem service that increasing soil cover and decreasing weed infestation by using the right combination of cover crops could represent for farmers in the short and especially in the long term. 2014).

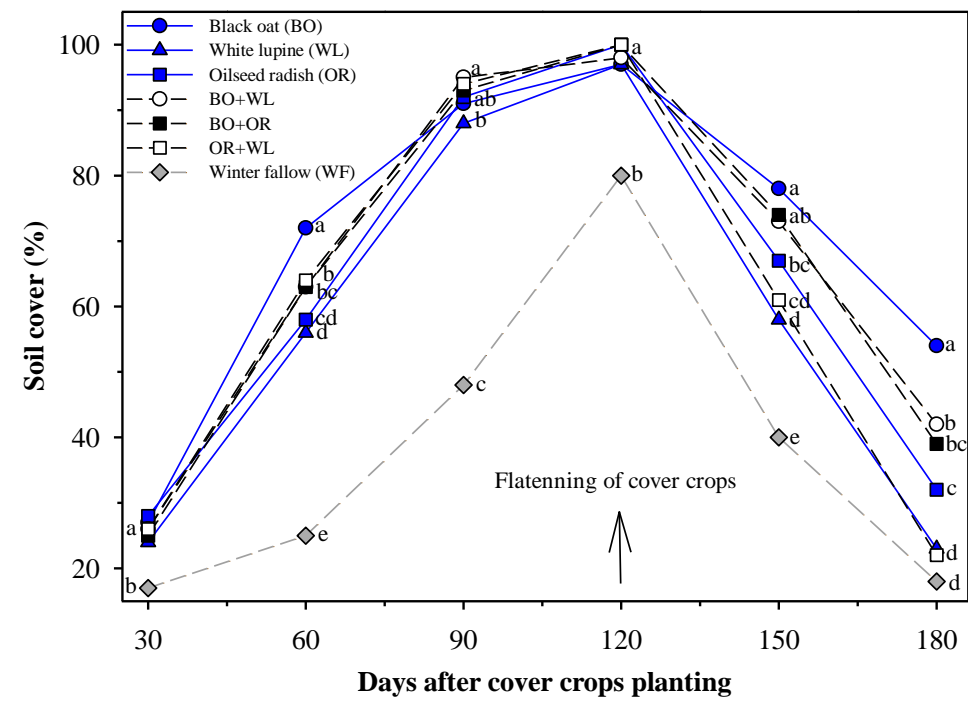

Figure 2. Percent soil cover as affected by single species cover crops, combinations and winter fallow during the 2009-2010 cropping season. Mean comparison with different letters at each sampling date are significantly different at the 0.1 probability level.

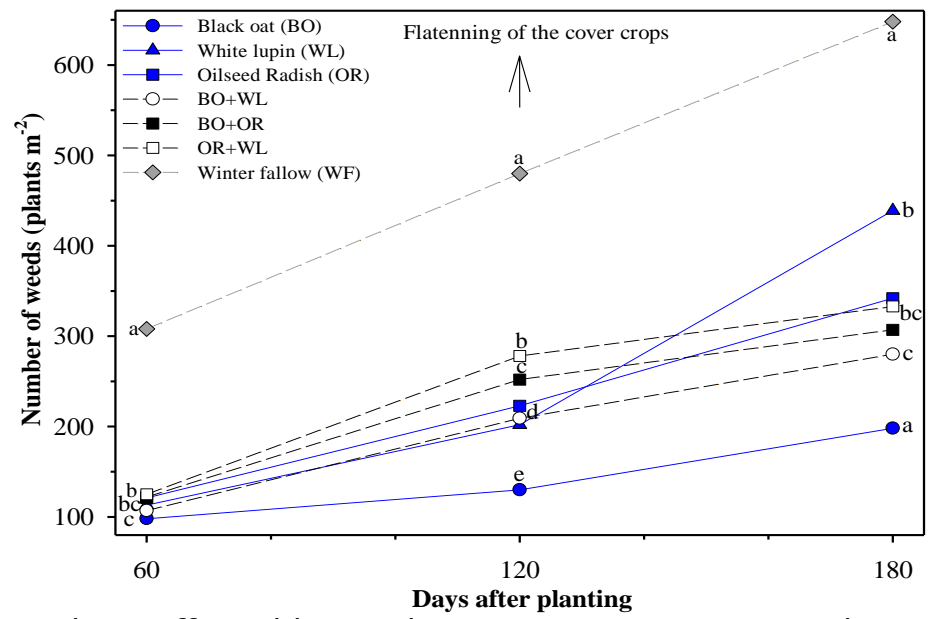

Figure 3. Number of weeds as affected by single species cover crops, combinations, and winter fallow at 60,90 , and 180 days after planting, during the 2009-2010 cropping season. Mean comparison with different letters are significantly different at the 0.1 probability level. 
The winter fallow treatment generated low biomass production (from weed infestation) (Table 3). However, the use of CC generated an average of 2.6 $\mathrm{t} \mathrm{ha}^{-1}$ higher biomass than winter fallow. Oilseed radish presented the highest $\mathrm{BP}\left(5 \mathrm{t} \mathrm{ha}^{-1}\right)$, providing high amount of residues to protect the soil. The overall biomass production by cover crops for this study can be considered normal compared to other research performed in similar soils in Paraguay (Florentín et al. 2011).

In contrast, however, Kubota et al. (2005), found BP by OR of $11 \mathrm{tha}^{-1}$ with fertilizer application and conducted in a soil with higher natural fertility (i.e. higher soil organic matter and clay content). Furthermore, chemical composition, quality and biomass could be greatly increased when mineral fertilizer is applied to cover crops (Rezende et al., 2017). In fact, fertilizing cover crops adequately have been suggested in order to ensure enough biomass production to protect the soil (Florentín et al. 2011) and help in nutrient cycling (Albuquerque et al. 2015).

Nevertheless, it is important to note the amount of biomass produced by the cover crops, even when no fertilizer was applied to them. In smallholder production systems of Paraguay, this may represent a great option, as it is more difficult for smallholder farmers to have access to mineral fertilizer. Nitrogen uptake (NU) was highest with the N-fixing WL (63 kg N ha-1), similar to the OR and combinations containing these two species (Table 3). Black oat accumulated the lowest amount of $\mathrm{N}$ when compared to other CC treatments. However, our study showed that this particular disadvantage can be overcome by mixing CC species, with significant increase in NU in the treatments with combination of cover crop species (Table 3).

Table 3. Biomass production and nitrogen uptake by single cover crops, combinations, and winter fallow during the 2009-2010 cropping season.

\begin{tabular}{|c|c|c|}
\hline Cover crops' & Biomass production & Nitrogen uptake \\
\hline & $\mathrm{t} \mathrm{ha}^{-1}$ & $\mathrm{~kg} \mathrm{ha}^{-1}$ \\
\hline $\mathrm{BO}$ & $3.0 \mathrm{~d}$ & $22 \mathrm{c}$ \\
\hline WL & $3.8 \mathrm{bc}$ & $63 a$ \\
\hline OR & $5.0 \mathrm{a}$ & $52 a b$ \\
\hline $\mathrm{BO}+\mathrm{WL}$ & $3.5 \mathrm{bcd}$ & $51 a b$ \\
\hline $\mathrm{BO}+\mathrm{OR}$ & $4.1 \mathrm{~b}$ & $41 \mathrm{~b}$ \\
\hline $\mathrm{OR}+\mathrm{WL}$ & $3.3 \mathrm{~cd}$ & $49 a b$ \\
\hline WF & $1.2 \mathrm{e}$ & $19 c$ \\
\hline$P<F$ & $<0.001$ & 0.005 \\
\hline
\end{tabular}

† Black oat (BO); White lupin (WL); Oilseed radish (OR); Winter fallow (WF). Mean comparison with different letters are significantly different at the 0.1 probability level.

Cover crop treatments increased SMN content before flattening (Figure 4), with an average of 4 $\mathrm{mg} \mathrm{kg}{ }^{-1}$ higher than winter fallow with no fertilizer $\mathrm{N}$ application. A small increase in SMN was observed 15 days after flattening (at the $0-10 \mathrm{~cm}$ soil layer), with values decreasing at 30 days after flattening. This may be due to some initial release of mineral $\mathrm{N}$ from the decomposition of cover crop residues and increasing maize $\mathrm{N}$ uptake at 30 days after flattening. All CC treatments, except for BO, showed similar amount of SMN. The lower $\mathrm{N}$ availability in cropping systems using $\mathrm{BO}$ has been reported in the literature (Aita et al. 2004, Leguizamón 2009), and the explanation is the higher $\mathrm{C} / \mathrm{N}$ ratio of this cover crop, which leads to higher $\mathrm{N}$ immobilization in the soil. However, Aita et al. (2004) found that when mixing legume cover crops with grass cover crops such as $\mathrm{BO}$, the $\mathrm{N}$ immobilization decreases and there is more available $\mathrm{N}$ for the corn plants to take up, which is in agreement with the observed in our study (Figure 4). White lupin and oilseed radish as single CC and mixed showed the higher levels of SMN at different sampling times and sampling depths (Figure 4). It is widely known that legume cover crops present the ability to fix atmospheric $\mathrm{N}$ symbiotically, which is a key environmental benefit (Köpke and Nemecek, 2010). These results agree with previous studies demonstrating that CC management can positively affect $\mathrm{N}$ availability in the soil-plant system (Derpsch et al. 2016, Gabriel et al. 2016, Tribouillois et al. 2016), especially legume cover crops, which present the benefit of fixing atmospheric $\mathrm{N}$, adding extra $\mathrm{N}$ to the system. Soil $\mathrm{N}$ dynamics is under studied in Paraguay and there are no reports in the scientific literature, thus the importance of these results. 


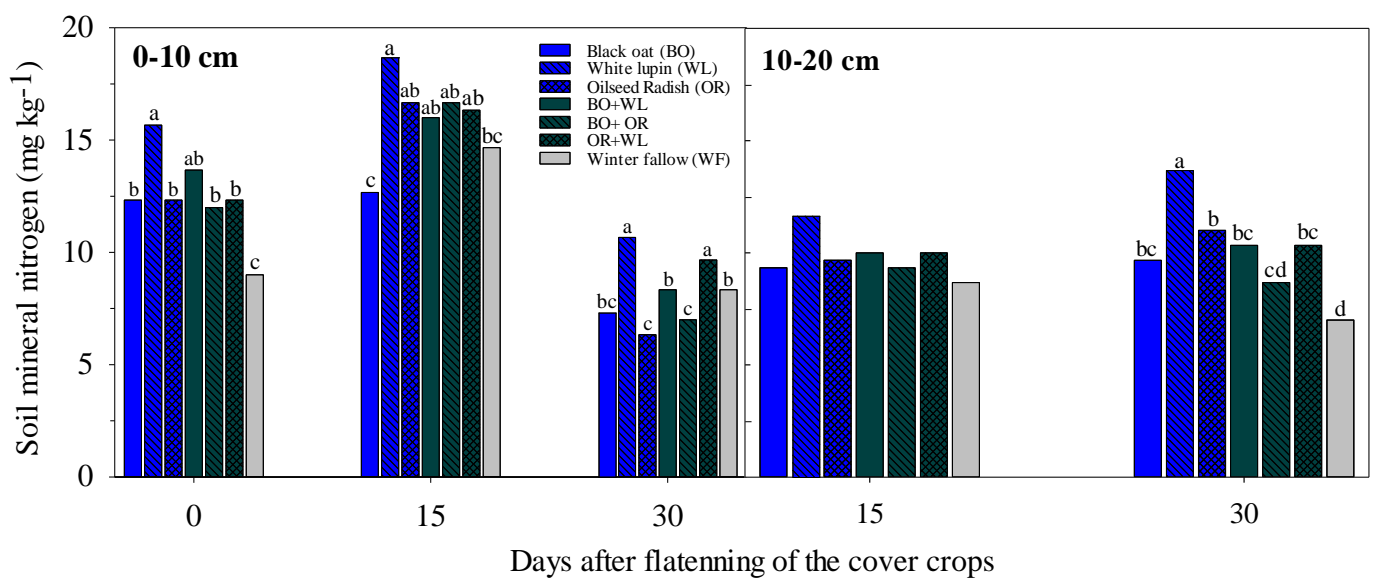

Figure 4. Soil mineral nitrogen content $\left(\mathrm{NH}_{4}{ }^{+}+\mathrm{NO}_{3}{ }^{-}\right)$as affected by single species cover crops, combinations, and winter fallow. Means comparison with different letters are significantly different at the 0.1 probability level.

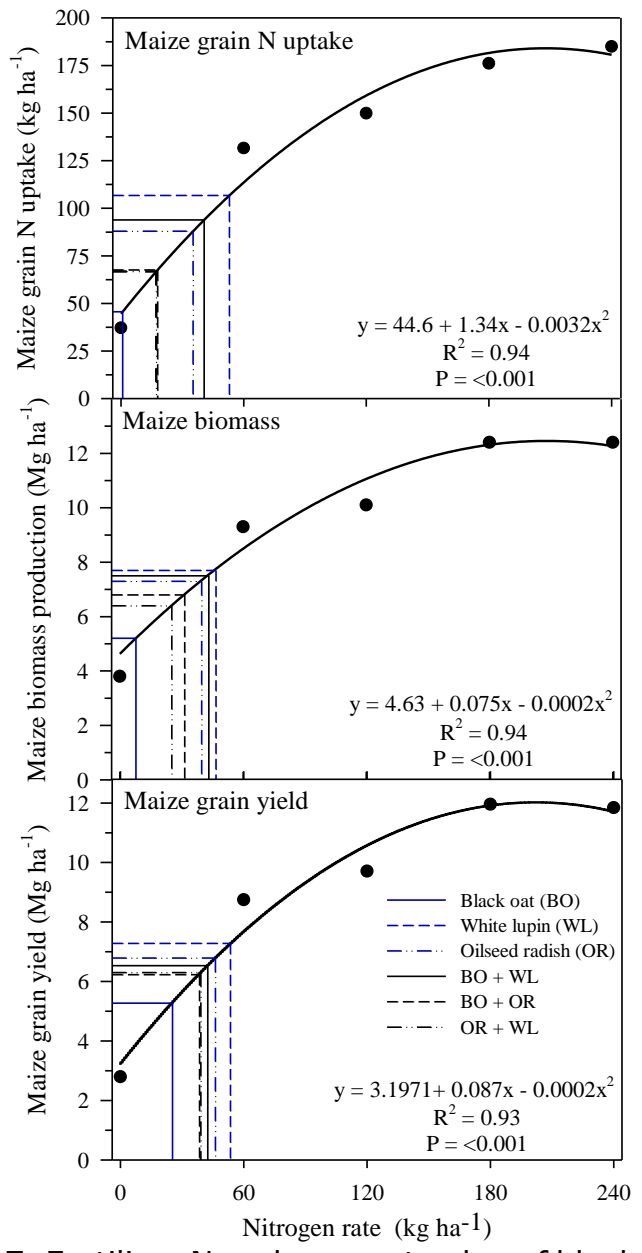

Figure 5. Fertilizer $\mathrm{N}$ replacement value of black oat (BO), white lupin (WL), oilseed radish $(\mathrm{OR})$, and their combinations for maize grain nitrogen uptake, maize biomass, and maize grain yield in the 2009-2010 growing season.
Cover crop treatments and $\mathrm{N}$ fertilizer rates (applied as urea) showed significant effect on maize grain $\mathrm{N}$ uptake, MBP, and MGY (Figure 5). In average, CC treatments lead to a yield increase of $3.6 \mathrm{t} \mathrm{ha}^{-1}$ when compared to the winter fallow treatment. Maize grain yield was increased by $1.8 \mathrm{Mg} \mathrm{ha}^{-1}$ when $B O$ is mixed with WL or OR compared to a single species of BO. White lupin and OR as single species showed the highest maize yield (Figure 5).

The benefits of legumes in the rotation are well known including the release of plant available $\mathrm{N}$ (Aita et al. 2004, Tully et al. 2015). Furthermore, crop rotation can have a substantial positive influence on maize yield beyond the potential $\mathrm{N}$ contributions (Mahama et al. 2016). The fertilizer $\mathrm{N}$ replacement values from the $\mathrm{CC}$ species evaluated in the study was positive and varied from $25-53 \mathrm{~kg}$ $\mathrm{N} \mathrm{ha}^{-1}$ (Figure 5).

The legume and brassica species provided the highest $N$ fertilizer replacement values, demonstrating the importance of including them in crop rotation systems. On the other hand, the grass specie (BO) provided lower soil $\mathrm{N}$ availability, which was attenuated when mixing it with $W L$ and $O R$.

A summary of the benefits of mixing cover crop species observed in this study is presented in Figure 6 , demonstrating this approach represents a good alternative to merge the positive characteristics of the individual species such as high $\mathrm{N}$ uptake, grain yield and $\mathrm{N}$ availability after $\mathrm{WL}$ and $\mathrm{OR}$, with the 
more lasting soil cover and great weed suppression characteristics of $\mathrm{BO}$.

Such results are in agreement with data from several parts of the world (Hodgdon et al. 2016, Ramírez-García et al. 2015, Tribouillois et al. 2016), which shows that including a legume cover crop such as WL can serve as green manure increasing $\mathrm{N}$ availability for the next crop and leading to higher crop yield, while cover crops with higher $\mathrm{C} / \mathrm{N}$ ratio such as BO can serve as catch crops, helping to decrease weed infestation and increase the soil cover durability of the cover crop residues. Mixing winter cover crops can represent a great alternative to attenuate the disadvantages and boost the advantages of some cover crops.

Results from this study provide useful information on the immediate (short-term) effect of CC on the following maize response and the ecosystem services provided by winter cover crops (combined

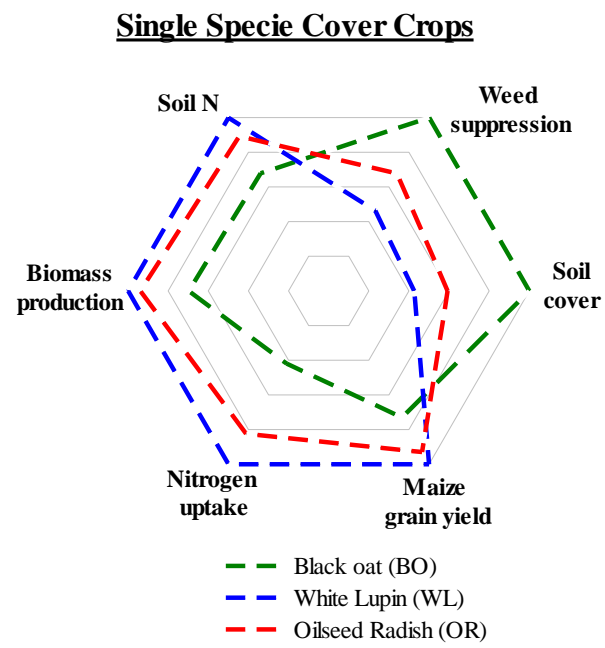

or not) such as soil cover, weed suppression, and $\mathrm{N}$ supply to the next crop (i.e. maize) leading to higher crop yield and other benefits (i.e. higher biomass production and $\mathrm{N}$ uptake) in current Paraguayan cropping systems and from other parts of the world. With these data, it is important to highlight the importance of including winter cover crops in the crop rotation systems, and especially in no-till soils, where a good soil cover is needed to ensure the sustainability of the production system as a whole.

Additional studies are needed to evaluate the longterm effect of multiple years and experimental sites of $\mathrm{CC}$ including the use of mix species that may provide the best combination for improved soil health and crop yield increase. These results will be of extremely importance for smallholder farmers struggling to increase crop yields. We also raise the question about the need for scientific publications of the results of the few existing long-term studies in Paraguay.

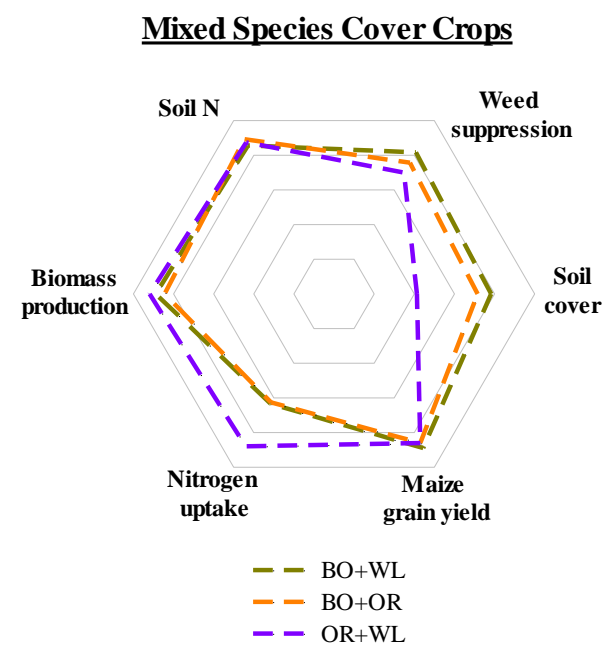

Figure 6. Ecosystem services provided by single and mixed species of cover crops in a subtropical Ultisol.

\section{CONCLUSIONS}

The winter cover crop species evaluated in this study supplied plant-available $\mathrm{N}$ to the subsequent maize crop. The replacement value of $\mathrm{N}$ fertilizer from the cover crops to the maize was up to $53 \mathrm{~kg}$ $\mathrm{N} \mathrm{ha}^{-1}$ (equivalent to $115 \mathrm{~kg}$ urea ha-1) with the use of the legume white lupin (WL). The lowest $N$ supply of plant available $\mathrm{N}$ was with the black oat (BO) of $25 \mathrm{~kg} \mathrm{~N} \mathrm{ha-1}$. The mix of species supplied plantavailable $\mathrm{N}$ between $38-42 \mathrm{~kg} \mathrm{~N} \mathrm{ha}^{-1}$.

Other ecosystem services provided by the CC included soil cover and reduced weed population.
Results from this study suggest that $\mathrm{BO}$ can be represented a good alternative to attain rapid soil cover. Black oat also provided better soil cover after $\mathrm{CC}$ flattening, likely due to the higher $\mathrm{C}: \mathrm{N}$ ratio and slower residue decomposition. Its higher $\mathrm{C}: \mathrm{N}$ ratio likely resulted in $\mathrm{N}$ immobilization, reflected in reduced plant available $\mathrm{N}$ to the maize crop. However, this study showed other benefits from good soil cover, particularly for suppression of weed population. Soil cover, weed suppression, soil mineral nitrogen dynamics, and maize grain yield were all positively affected by the use of CC, regardless of their use as single species or in a mix. Combining winter cover crops can help to merge the 
benefits and attenuate the disadvantages of each $\mathrm{CC}$, reflecting in more sustainable crop production systems.

\section{AKNOWLEDGMENTS}

We are grateful to Centro de Tecnología Agropecuaria en el Paraguay (CETAPAR) and to the soil testing lab of the Department of Soils and Territorial Organization (DESOT, FCA/UNA) for support and equipment for soil and plant analysis. This is contribution no. 17-170-J from the Kansas Agricultural Experiment Station.

\section{BIBLIOGRAPHIC REFERENCES}

Abendroth, LJ; Elmore, RW; Boyer, MG; Marlay, SK. 2011. Corn Growth and Development. Ames, Iowa: ISU.

Aita, C; Giacomini, SJ; Hubner, AP; Chiapinotto, IC; Fries, MR. 2004. Consorciação de plantas de cobertura antecedendo o milho em plantio direto: I - Dinâmica do nitrogênio no solo. Revista Brasileira de Ciência do Solo 28: 739749.

Albuquerque, MA; Dieckow, J; Sordi, A; Piva, JT; Bayer, C; Molin, R; Pergher, M; Ribeiro-Junior, PJ. 2015. Carbon and nitrogen in a Ferralsol under zero-tillage rotations based on cover, cash or hay crops. Soil Use and Management 31: 1-9.

Bender, RR; Haegele, JW; Ruffo, ML; Below, F. 2013. Nutrient uptake, partitioning, and remobilization in modern transgenic insectprotected maize hybrids. Agronomy Journal 105: 161-170.

Bouyoucos, GJ. 1962. Hydrometer method improved for making particle size analysis of soils. Agronomy Journal 54:464-465.

Blanco-Canqui, $\mathrm{H}$; Shaver, TM; Lindquist, JL; Shapiro, CA; Elmore, RW; Francis, CA; Hergert, GW. 2015. Cover crops and ecosystem services: insights from studies in temperate soils. Agronomy Journal 107: 2449-2474.

Derpsch, R; Lange, D; Birbaumer, G; Moriya, K. 2016. Why do medium- and large-scale farmers succeed practicing $\mathrm{CA}$ and small-scale farmers often do not? - experiences from Paraguay. International Journal of. Agricultural Sustainability 14: 269-281.

Derpsch, R; Franzluebbers, AJ; Duiker, SW; Reicosky, DC; Koeller, K; Friedrich, T; Sturny,
WG; Sá, JCM; Weiss, K. 2014. Why do we need to standardize no-tillage research? Soil and Tillage Research 137: 16-22.

DMH (Dirección de Meteorología e Hidrología). 2015. Mapas normales de la precipitación mensual y anual. Available at http://www.meteorologia.gov.py/publicaciones. php/ (accessed 05.10.16)

Fatecha, A. 1999. Guía para la fertilización de cultivos anuales y perennes de la Region Oriental del Paraguay. Boletín Técnico 1. San Lorenzo, Paraguay, Sociedad Paraguaya de Ciencia del Suelo (SOPACIS). 33 p.

Finney, DM; White, CM; Kaye, JP. 2016. Biomass production and carbon/nitrogen ratio influence ecosystem services from cover crop mixtures. Agronomy Journal 108: 39-52.

Florentin, MA; Peñalva, M; Calegari, A; Derpsch, R. 2011. Green manure/cover crops and crop rotation in conservation agriculture on small farms. Translated by McDonald, MJ. Integrated Crop Management Vol. 12-2010. Rome, Italy, Food and Agriculture Organization of the United Nations (FAO). 97 p.

Flower, KC; Cordingley, N; Ward, PR; Weeks, C. 2012. Nitrogen, weed management and economics with cover crops in conservation agriculture in a Mediterranean climate. Field Crops Research 132: 63-75.

Fontoura, SMV; Bayer, C. 2009. Adubacão nitrogenada para alto rendimento de milho em plantio direto na região Centro-Sul do Parana. Revista Brasileira de Ciência do Solo 33: 17211732.

Frasier, I; Noellemeyer, E; Figuerola, E; Erijman, L; Permingeat, $\mathrm{H}$; Quiroga, A. 2016. High quality residues from cover crops favor changes in microbial community and enhance $\mathrm{C}$ and $\mathrm{N}$ sequestration. Global Ecology and Conservation 6: 242-256.

Gabriel, JL; Alonso-Ayuso, M; García-González, I; Hontoria, C; Quemada, M. 2016. Nitrogen use efficiency and fertiliser fate in a long-term experiment with winter cover crops. European Journal of Agronomy 7: 14-22.

Giacomini, SJ; Aita, C; Chiapinotto, IC; Hübner, AP; Marques, MG; Cadore, F. 2004. Consorciação de plantas de cobertura antecedendo o milho em plantio direto. II - Nitrogênio acumulado pelho milho e produtividade de grãos. Revista Brasileira de Ciência do Solo 28: 751-762. 
Hodgdon, EA; Warren, ND; Smith, RG; Sideman, RG. 2016. In-season and carry-over effects of cover crops on productivity and weed suppression. Agronomy Journal 108: 1624-1635.

Kaundun, SS; Hutchings, SJ; Harris, SC; Jackson, LV; Shasi-Kiran, R; Dale, RP; McIndoe, E. 2014. A simple in-season bioassay for detecting glyphosate resistance in grass and broadleaf weeds prior to herbicide application in the field. Weed Science 62: 597-607.

Köpke, U; Nemecek, T. 2010. Ecological services of faba bean. Field Crops Research 115: 217-233.

Kubota, A; Hoshiba, K; Bordon, J. 2005. Greenmanure turnip for soybean based no-tillage farming systems in Eastern Paraguay. Scientia Agricola 62: 150-158.

Leguizamón Rojas, CA. 2009. Dinâmica do nitrogênio no sistema latossolo-milho sob plantio direto e prepare convencional, plantas de cobertura de inverno e adubação nitrogenada. Tesis de Doctorado. Porto Alegre, Brasil, Universidade Federal do Rio Grande do Sul. 181 p.

Lopez, O; Gonzalez, E; Llamas, P; Molinas, A; Franco, E; Garcia, S; Rios, A. 1995. Mapa de Reconocimiento de Suelos de la Region Oriental. Escala 1500.00. Color. Asunción, Paraguay, Banco Mundial (BM).

Lundy, ME; Pittelkow, CM; Linquist, BA; Liang, $\mathrm{X}$; van Groenigen, KJ; Lee, J; Six, J; Venterea, RT; van Kessel, C. 2015. Nitrogen fertilization reduces yield declines following no-till adoption. Field Crops Research 183: 203-210.

Mahama, GY; Vara Prasad, PV; Roozeboom, KL; Nippert, JB; Rice, CW. 2016. Response of maize to cover crops, fertilizer nitrogen rates, and economic return. Agronomy Journal 108: 17-31.

Price, AJ; Reeves, DW; Patterson, MG. 2006. Evaluation of weed control provided by three winter cereals in conservation-tillage soybean. Renewable Agriculture Food System 21: 159164.

Raij, B van. 2011. Fertilidade do solo e manejo de nutrientes. Piracicaba, Brasil, International Plant Nutrition Institute (IPNI). 420 p.
Ramírez-Garcia, J; Carrillo, JM; Ruiz, M; AlonsoAyuso, M; Quemada, M. 2015. Multicriteria decision analysis applied to cover crop species and cultivar selection. Field Crops Research 175: 106-115.

Rezende, AV, Rabêlo, FHS; González-Villalba, HA; Swerts, VA; Dupas, E; Florentino, LA; Rabêlo, CHS; Correr, ACD. 2017. Organic matter production and chemical composition of cover crops fertilized with NPK. Experimental Agriculture 53: 242-254.

SAS Institute. 2014. SAS 9.4 Language reference: concepts. SAS Institute Inc. Cary, NC, USA. 828 p.

Shoemaker, HE; McLean, EO; Pratt, PF. 1961. Buffer methods for determining lime requirement of soils with appreciable amounts of extractable Aluminum. Soil Sci. Soc. Am. J. 25: 274-277.

Tedesco, MJ; Gianello, C; Bissani, CA; Bohnen, H; Volkweiss, SJ. 1995. Análises de solo, plantas e outros materiais. Porto Alegre, Brasil, Universidade Federal do Rio Grande do Sul (UFRGS). 174 p.

Tosti, G; Benincasa, P; Farneselli, M; Tei, F; Guiducci, M. 2014. Barley-hairy vetch mixture as cover crop for green manuring and the mitigation of $\mathrm{N}$ leaching risk. European Journal of Agronomy 54: 34-39.

Tribouillois, H; Cohan, JP; Justes, E. 2016. Cover crop mixtures including legume produce ecosystem services of nitrate capture and green manuring: assessment combining experimentation and modelling. Plant Soil 401: 347-364.

Tully, K; Wood, SA; Almaraz, M; Neill, C; Palm, C. 2015. The effect of mineral and organic nutrient input on yields and nitrogen balances in Western Kenya. Agriculture Ecosystems and Environment 214: 10-20.

Varela, MF; Scianca, CM; Taboada, MA; Rubio, G. 2014. Cover crop effects on soybean residue decomposition and $\mathrm{P}$ release in no-tillage systems of Argentina. Soil and Tillage Research 143: $59-66$ 